\title{
Literature review of Triple-negative breast cancer metastasis to lungs and its management through Chemotherapy
}

\author{
Article by Kavita Gupta \\ $P h D$ in Clinical Research, Texila American University \\ Email id: 16kavitagupta@gmail.com
}

\begin{abstract}
The present study is a review of literature that covers an aspect of role of BRCA1 gene mutation in breast cancer metastasis, risk of recurrence influenced by stage at initial presentation, the underlying biology of the tumor, time of relapse after diagnosis of the primary tumor, reasons for metastasis, various biological markers discovered up till date, discussion of several mathematical models, with a focus on how they have been used to predict the initiation time of metastatic growth, and standard choice of treatment best suited for triple negative breast cancer metastasis.

Breast cancer starts as a local disease, but it could metastasize to the lymph nodes and distant organs. As by definition, Metastatic breast cancer, also known as Advanced or Stage IV breast cancer, is the stage in breast cancer progression in which malignant cells from the primary tumor successfully create new tumors in distant organs. According to the Research studies, women who have BRCA1 mutations are at higher risk for triple negative breast cancer. The prognosis of women with triple negative breast cancers (ER-negative, PR-negative and HER2-neu -negative) is poor as compared to women with other subtypes of breast cancer. TNBC relapses more frequently than hormone receptor-positive subtypes and is often associated with poor outcomes.

Patients and oncologists always have a dilemma on how to cope with this aggressive disease. For patients, the diagnosis of breast cancer is fearsome; so when they know additionally that they suffer from TNBC-a subtype with poor outcomes - this situation is often more stressful. TNBC patients have a unique pattern of relapse, which occurs mostly in the first 3 years following diagnosis. Although metastatic breast cancer is not curable, meaningful improvements in survival have been seen, coincident with the introduction of newer systemic therapies.
\end{abstract}

Keywords: TNBC (Triple Negative Breast Cancer), Metastasis, tumor, ERnegative, PR-negative, HER2-neu negative, BRCA1 mutations, Overall Survival, Lungs, Mathematical Models, Recurrence, Chemokines, Chemotherapy.

\section{Introduction}

The aim of this review study is to assess the rate, pattern and time of recurrence in patients with TNBC and to evaluate factors influencing recurrence and overall survival in this group of patients. The preferential site of metastasis varies by breast cancer subtype, with TNBC preferring visceral organs, for example, the lungs (Pogoda et al., 2013). A major goal of this study is to identify the genes that drive metastasis in patients with TNBC and determine their mechanism of action (Pogoda et al., 2013). The goals of the study are to:

(i) Identify the transcriptional changes that drive breast cancer metastasis to the lungs (Pogoda et al., 2013).

(ii) Functionally characterize how these changes contribute to breast cancer metastasis (Pogoda et al., 2013).

(iii) Validate the findings in human breast cancer samples (Pogoda et al., 2013).

(iv) Clinical and Preclinical Evidences to support the study. 
This review would highlight focus on molecular features, risk/epidemiological factors, patterns of metastatic spread, prognostic implications, novel "targets", and emerging therapeutic strategies for this clinically challenging and aggressive entity. Tumor metastasis is a multistage process during which malignant cells spread from the primary tumor to distant organs (Talmadge \& Fidler, 2010). A person who has a BRCA1 mutation is called as BRCA1 carrier and BRCA1 carriers have a 55 to $65 \%$ chance of developing breast cancer by the age of 70 (Deng, 2006).

Triple negative is an unsatisfactory category in the following 3 ways:

1. It is not a biologically homogeneous subgroup (Pestalozzi, 2009).

2. It does not help to select a particular treatment (Pestalozzi, 2009).

3. Overall prognosis is poor (Pestalozzi, 2009).

\section{Pathogenesis of metastasis}

The term "Metastasis" was coined in 1829 by Jean Claude Recaimer (Talmadge \& Fidler, 2010). The pathogenesis of metastasis involves a series of steps, dependent on both the intrinsic properties of the tumor cells and the host response (Talmadge \& Fidler, 2010).The spread of cancer or metastasis entails various biological processes.

1. The Cancer cells invade nearby healthy cells. When the healthy cell is taken over, it too could replicate more abnormal cells (Talmadge \& Fidler, 2010).

2. Cancer cells penetrate into the circulatory or lymph system. Cancer cells travel through the walls of nearby lymph vessels or blood vessels (Talmadge \& Fidler, 2010).

3. Migration through circulation. Cancer cells are carried by the lymph system and the bloodstream to other parts of the body (Talmadge \& Fidler, 2010).

4. Cancer cells lodge in capillaries. Cancer cells stop moving as they are lodged in capillaries at a distant location and divide and migrate into the surrounding tissue (Talmadge \& Fidler, 2010).

5. New small tumors grow. Cancer cells form small tumors at the new location (called micrometastasis) (Talmadge \& Fidler, 2010).

Below given is the illustration of pathogenesis of Metastasis as hypothesized by different authors:

Table 1: Pathogenesis of metastasis

\begin{tabular}{|c|l|}
\hline Author/ Study & \multicolumn{1}{|c|}{ Hypothesis/Theory } \\
\hline Stephen Paget & $\begin{array}{l}\text { Identification of the role of host-tumor } \\
\text { cell interactions. } \\
\text { Remarks: High incidence of metastasis to } \\
\text { the liver, ovary due to discrepancy } \\
\text { between the blood supply and frequency } \\
\text { of metastasis to specific organs (Talmadge } \\
\text { \& Fidler, 2010). }\end{array}$ \\
\hline Virchow Theory & $\begin{array}{l}\text { Metastasis could be explained simply by } \\
\text { the arrest of tumor-cell emboli in the } \\
\text { vasculature (Talmadge \& Fidler, 2010). }\end{array}$ \\
\hline Paget Observation & $\begin{array}{l}\text { Remote organs cannot be altogether } \\
\text { passive or indifferent regarding embolism } \\
\text { (Talmadge \& Fidler, 2010). }\end{array}$ \\
\hline Ewing & $\begin{array}{l}\text { Mechanical forces and circulatory patterns } \\
\text { between the primary tumor and the } \\
\text { secondary site accounted for organ } \\
\text { specificity (Talmadge \& Fidler, 2010). }\end{array}$ \\
\hline
\end{tabular}




\begin{tabular}{|l|l|}
\hline Fidler \& coworkers & $\begin{array}{l}\text { Although tumor cells traffic through the } \\
\text { vasculature of all the organs, metastases } \\
\text { selectivity develops in congenital organs } \\
\text { (Talmadge \& Fidler, 2010). }\end{array}$ \\
\end{tabular}

Source: AACR Centennial Series: The Biology of Cancer Metastasis: Historical Perspective, (2010) (Talmadge \& Fidler, 2010).

\section{Biology of Metastasis}

Table 2: Biology of metastasis

\begin{tabular}{|c|c|}
\hline YEAR & Theory \\
\hline 1991 & $\begin{array}{l}\text { Relationship between Metastasis and Angiogenesis in breast } \\
\text { cancer (Talmadge \& Fidler, 2010). }\end{array}$ \\
\hline 1992 & $\begin{array}{l}\text { Role of chemokines in tumor- associated macrophage facilitation } \\
\text { of metastasis (Talmadge \& Fidler, 2010). }\end{array}$ \\
\hline 1994 & $\begin{array}{l}\text { Removal of malignant primary tumor in mice spurs growth of } \\
\text { remote tumors, or Metastases (Talmadge \& Fidler, 2010). }\end{array}$ \\
\hline 1997 & $\begin{array}{l}\text { Visualization of tumor cell invasion and metastases using GFP } \\
\text { expression (Talmadge \& Fidler, 2010). }\end{array}$ \\
\hline 2000 & $\begin{array}{l}\text { Gene expression pattern diversity in breast cancer tissue } \\
\text { (Talmadge \& Fidler, 2010). }\end{array}$ \\
\hline 2001 & $\begin{array}{l}\text { Role of cancer stem cells in Metastasis (Talmadge \& Fidler, } \\
\text { 2010). }\end{array}$ \\
\hline 2002 & $\begin{array}{l}\text { EMT could explain metastatic progression (Talmadge \& Fidler, } \\
\text { 2010). }\end{array}$ \\
\hline 2002 & $\begin{array}{l}\text { Heterogeneity of single disseminated tumor cells in minimal } \\
\text { residual cancer (Talmadge \& Fidler, 2010). }\end{array}$ \\
\hline 2002 & $\begin{array}{l}\text { Metastatic potential determined early in tumorigenesis; metastatic } \\
\text { molecular signature in primary tumor (Talmadge \& Fidler, 2010). }\end{array}$ \\
\hline 2002 & $\begin{array}{l}\text { Gene-expression profile of primary breast cancer associated with } \\
\text { metastasis and poor outcome (Talmadge \& Fidler, 2010). }\end{array}$ \\
\hline 2003 & $\begin{array}{l}\text { Breast cancer metastasis ability resides in a few breast cancer } \\
\text { stem cells by highly resistant to chemotherapy (Talmadge \& } \\
\text { Fidler, 2010). }\end{array}$ \\
\hline 2006 & $\begin{array}{l}\text { Role of genetic susceptibility for metastasis (Talmadge \& Fidler, } \\
2010) \text {. }\end{array}$ \\
\hline 2007 & $\begin{array}{l}\text { First metastasis-promoting micro-RNA (Talmadge \& Fidler, } \\
2010 \text { ). }\end{array}$ \\
\hline 2008 & $\begin{array}{l}\text { Micro-RNA expression patterns can predict metastatic risk } \\
\text { (Talmadge \& Fidler, 2010). }\end{array}$ \\
\hline 2008 & Micro-RNAs can suppress metastases (Talmadge \& Fidler, 2010). \\
\hline
\end{tabular}

\section{Classification of breast cancer metastasis}

1. Local Recurrence: It is the breast area where the cancer was originally diagnosed

(As

cited

in 
http://www.breastcancer.org/symptoms/types/recur_metast/where_recur/metas tic).

2. Regional Recurrence: Spread of the cancer cell to the lymph nodes in the armpit or collarbone area where the cancer was originally diagnosed (As cited in

http://www.breastcancer.org/symptoms/types/recur_metast/where_recur/metas tic).

3. Metastatic or Distant Recurrence: Spread of cancer to another part of the body such as lungs, bones, or brain (As cited in http://www.breastcancer.org/symptoms/types/recur_metast/where_recur/metas tic).

4. Symptoms of Metastatic Recurrence: According to the American Society of Clinical Oncology (ANCO) guidelines on breast cancer follow-up and management, symptoms of breast cancer recurrence include presence of new breast lumps, pain in the bone, chest or abdomen, dyspnea and constant headaches (Scully et al., 2012). Various other symptoms included, Constant back, bone or joint pain, Difficulty with urinating, Numbness or weakness anywhere in the body, Constant dry cough, Difficulty breathing, Shortness of breath, Chest pain, Loss of appetite, Abdominal bloating, pain or tenderness, Constant nausea, vomiting or weight loss, Jaundice, Severe headaches, Vision problems (blurry vision, double vision, loss of vision), Seizures, Loss of balance (unsteadiness), Confusion, Difficulty with speech, Memory problems, Changes in Pleural effusion (As cited in http://www.breastcancer.org/symptoms/types/recur_metast/where_recur/metas tic).

Pathological features of Tumor with TNBC BRCA1 mutations: Various pathological features included, High grade cancers, High mitotic index, Lymphocytic infiltrate, "Pushing" tumor margins with smooth edges, High proliferation rate, Nuclear Pleomorphism, Ductal and metaplastic histology, p53 mutations (Anders et al., 2009) \& (Hedenfalk et al., 2001). Moreover, TNBC tumors often present as interval cancers with weak relationship between tumor size and node status (Dent et al., 2007).

Immunophenotypic characteristics of Tumor with TNBC BRCA1 mutations: It includes the properties such as Estrogen receptor negative, HER 2 negative, Pcadherin negative, P63 negative, C-kit positive, Vimentin positive, Cytokeratin positive (Anders et al., 2009) \& (Hedenfalk et al., 2001).

1. Epidemiology of Triple-negative breast cancer: The incidence of breast cancer is increasing almost everywhere throughout the world (Boyle, 2012). Only a decade ago, breast cancer was considered a relatively 'simple' disease in many respects, with focus essentially on quantifying whether a tumor was, or was not, dependent on estrogen, a situation which had lasted for a century (Boyle, 2012). A quiet revolution has occurred, and breast cancer is now characterized by its molecular and clinical heterogeneity (Boyle, 2012). Perou et al. were the first to describe the various molecular sub-types or molecular profiles of breast cancers (As cited in http://www.breastcancer.org/symptoms/types/recur_metast/where_recur/metas tic).

5. They described four sub-types based on cDNA micro-arrays, including a basal-like sub-type of breast cancer, and noted that most triple-negative tumors clustered in the basal-like sub-type (As cited in http://www.breastcancer.org/symptoms/types/recur_metast/where_recur/metas tic). 
Of the global breast cancer burden, it has been estimated that $\sim 170000$ are TNBC and are often, but not always, basal-like breast cancer; another study has estimated that $\sim 75 \%$ are basal-like (Boyle, 2012).

Studies have shown that breast cancers in women with germ line BRCA-1 mutations are more likely to be triple negative and high grade (Ismail-Khan \& Bui 2010). Gene expression studies have confirmed this phenomenon and BRCA-1associated breast cancer appear to cluster in the basal-like subtype (Ismail-Khan \& Bui, 2010). The highest risk of relapse in TNBC patients is between the first and third year after primary treatment (Pogoda et al., 2013). In cases of recurrence, the survival is shorter than in non-TNBC patients (Pogoda et al., 2013). The global cancer control, GLOBOCAN series summarized cancer incidence and mortality in 182 countries (Anderson et al., 2013). The data indicated that breast cancer was the most frequent cancer in women, the second most frequent cancer overall and the leading cause of all cancer death in women (Anderson et al., 2013). A treatment approach that stratifies subtypes and receptor status will allow for an optimal and unique therapeutic advantage (Anderson et al., 2013). The tumor classification depends on the size and extent of tumor in the breast (Anderson et al., 2013).

Cancer Susceptibility Gene: BRCA1: It is mapped to a region on chromosome 17q through linkage studies (Marcus et al., 1996). If the tumors are "negative" then there are few or none receptors. TNBC is very unique as it is very aggressive and tends to grow faster (Marcus et al., 1996). It could be treated but it might recur early and spread to other parts of the body due to lack of targeted treatments (Marcus et al., 1996). Metastasis can be viewed as an evolutionary process, culminating in the prevalence of rare tumor cells that overcame stringent physiological barriers as they separated from their original environment and developmental fate (Nguyen et al., 2007). This phenomenon brings into focus long-standing questions about the stage at which cancer cells acquire metastatic abilities, the relationship of metastatic cells to their tumor of origin, the basis for metastatic tissue tropism, the nature of metastasis predisposition factors and, importantly, the identity of genes that mediate these processes fate (Nguyen et al., 2007).

Breast Cancer Subtypes: Breast cancer can be divided into subtypes based upon a common phenotype or genotype that co-relates with a consistent response to certain treatments (Anderson et al., 2013). The most common phenotype, hormone receptor positive breast cancer, is characterized by expression of either or both the estrogen receptor (ER) and Progesterone receptor (PR) (Anderson et al., 2013). The normal breast cancer subtype is poorly characterized and appears to possess an intrinsic subtype similar to fibroadenomas and normal breast samples (Anderson et al., 2013). Basal breast tumors are almost entirely estrogen-, progesterone-, and HER2-negative, making the triple-negative phenotype a sensitive and practical surrogate marker for basal breast cancer (Kennecke et al., 2010). The 4 molecular subgroups of breast cancer vary importantly with respect to clinical features, natural history, and outcomes (Kennecke et al., 2010). In particular, the basal or triple-negative phenotype appears to have a more aggressive course than other breast cancers, with shorter disease-free survival and overall survival (OS) times (Kennecke et al., 2010).

Evidence: The fact that the majority of BRCA1-associated breast cancers are also triple-negative and basal-like leads researchers to wonder about the extent to which the BRCA1 pathway contributes to the behavior of "sporadic" basal-like breast cancers (Ismail-Khan \& Bui, 2010). It has been shown that basal-like breast carcinomas frequently harbor defects in DNA double-strand break repair through homologous recombination such as BRCA1 dysfunction (Ismail-Khan \& Bui, 2010). 
South American Journal of Clinical Research

Special Edition 2016

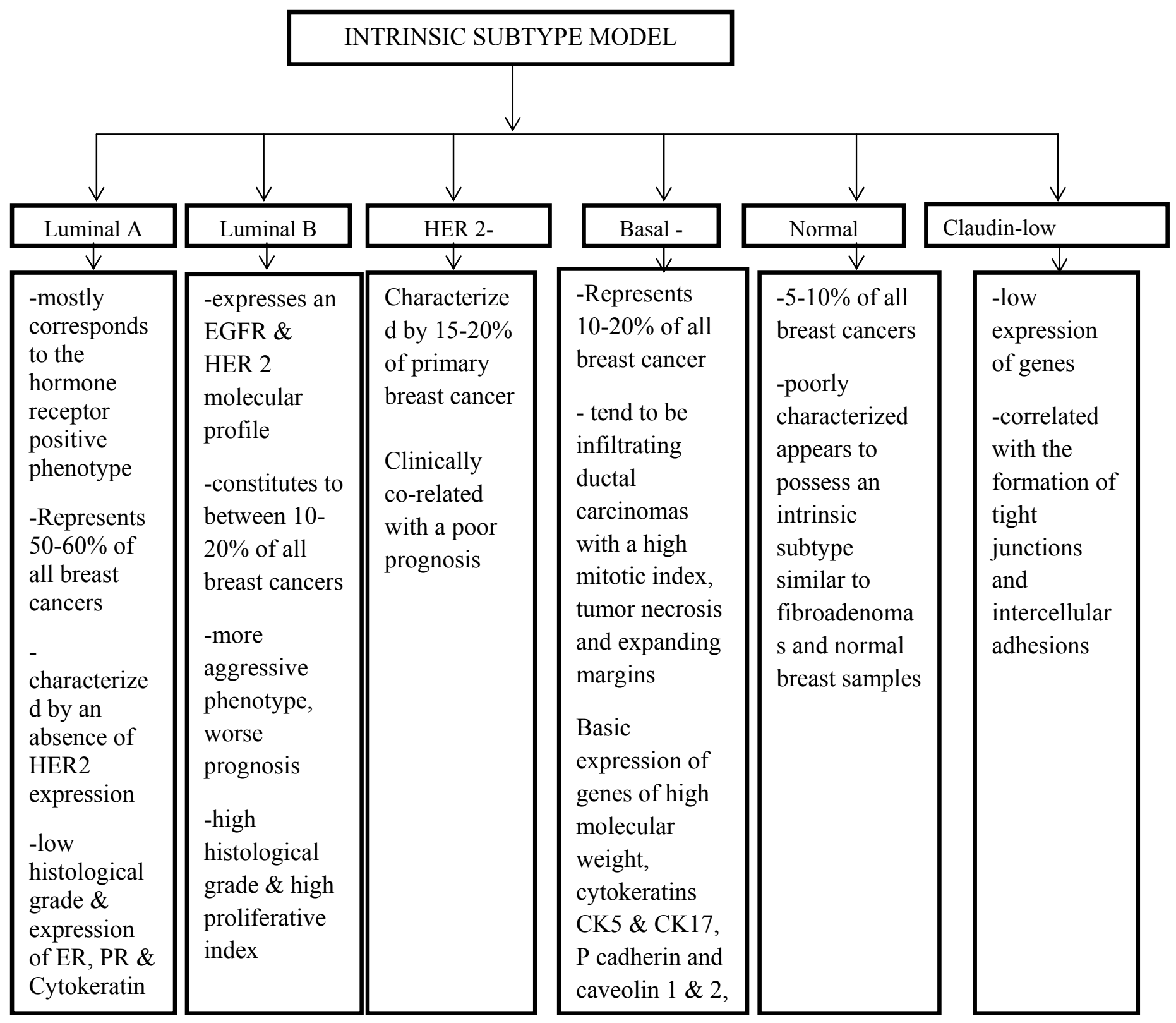

Figure 1: Breast cancer subtypes

Source: A clinical primer for Translational Investigation, (2013) (Anderson et al., 2013). 


\section{Molecular Biology of Breast Metastasis: Mathematical Models}

These models are used to predict the initiation time of Metastatic growth (Clare et al., 2000).

Table 3: Mathematical models representing molecular biology of breast metastasis.

\begin{tabular}{|c|c|}
\hline Mathematical Model & Description \\
\hline 1. Gompertz Model & $\begin{array}{l}\text { Mainstay for models of solid tumors, } \\
\text { including breast cancer for a } \\
\text { considerable period of time. } \\
\text { This model is a modification of } \\
\text { exponential growth, with the addition of } \\
\text { a decreasing growth rate over time. } \\
\text { This decelerated growth causes the } \\
\text { cancer to asymptotically approach a } \\
\text { limiting size, referred to as its carrying } \\
\text { capacity. } \\
\text { This limited growth is attributed to } \\
\text { several factors, including hypoxia and } \\
\text { the lack of nutrients (Clare et al., 2000). }\end{array}$ \\
\hline 2. Speer et al. Model & $\begin{array}{l}\text { Observation of the subclinical duration } \\
\text { of growth given by the original } \\
\text { Gompertz growth equation, using a range } \\
\text { of parameter values which is too short, } \\
\text { i.e., approx. } 4 \text { months (Clare et al., } \\
\text { 2000). }\end{array}$ \\
\hline 3. Spratt et al. Model & $\begin{array}{l}\text { Indicated that, although the original } \\
\text { Gompertz model can give a good } \\
\text { approximation to clinical tumor growth } \\
\text { over the short term, the growth rate of } \\
\text { the cancer is more likely to be stochastic } \\
\text { over the full history of the cancer. This } \\
\text { allows for various growth patterns, } \\
\text { including dormancy (Clare et al., 2000). }\end{array}$ \\
\hline 4. Spratt et al. Model & $\begin{array}{l}\text { Determined from the mammogram data } \\
\text { that the median doubling time is } 260 \\
\text { days for breast tumors at detectable } \\
\text { levels. } \\
\text { In fact, he considered one of the slower } \\
\text { growing breast cancers that they } \\
\text { observed, with a doubling time of } 7051 \\
\text { days (Clare et al., 2000). }\end{array}$ \\
\hline 5. Koscienlny et al. Model & $\begin{array}{l}\text { Concluded that the metastatic doubling } \\
\text { time is } 2.2 \text { times faster than that of the } \\
\text { primary. } \\
\text { The number of cells needed for } \\
\text { metastatic initiation is greater than a } \\
\text { single cell. } \\
\text { The growth duration of metastasis is } \\
\text { approx. } 3.8 \text { years (Clare et al., 2000). }\end{array}$ \\
\hline
\end{tabular}




\begin{tabular}{|l|l|}
\hline $\begin{array}{l}\text { 6. Retsky \& coworkers, Denicheli et } \\
\text { al., Swartzendruber et al. }\end{array}$ & $\begin{array}{l}\text { Smaller tumors with good prognostic } \\
\text { factors tend to relapse under the second } \\
\text { peak of the frequency of the relapse } \\
\text { curve, at around 5 years (Clare et al., } \\
\text { 2000). }\end{array}$ \\
\hline 7. Norton \& Simon Model & $\begin{array}{l}\text { Assured that all tumor growth, tumor } \\
\text { regression and tumor regrowth is } \\
\text { Gompertzian. that } \\
\text { Suggested that when treating } \\
\text { micrometastasis; high dose, short- } \\
\text { duration treatment might be preferable to } \\
\text { prolonged duration, low-dose therapy } \\
\text { (Clare et al., 2000). }\end{array}$ \\
\hline 8. Goldie - Coldman Model & $\begin{array}{l}\text { Assumed that at each cell division of a } \\
\text { non-mutant tumor cell, there exists a } \\
\text { fixed non-zero probability that any new } \\
\text { daughter cell will be a resistant mutant. } \\
\text { By the time a tumor is detected, that is, } \\
\text { by the time it reaches 10 cells, the } \\
\text { Goldie-Coldman model estimated that } \\
\text { drug-resistant mutants were present } \\
\text { (Clare et al., 2000). }\end{array}$ \\
\hline
\end{tabular}

Source: Molecular biology of breast metastasis: The use of mathematical models to determine relapse and to predict response to chemotherapy in breast cancer, (2000) (Clare et al., 2000).

According to Gompertzian kinetics, as the tumor becomes smaller, its growth fraction increases and it regrows at a faster rate. (Clare et al., 2000). At some point the rate of cell kill might equal the rate of cell repopulation, and the cell population would approach asymptotic limit (Clare et al., 2000). If the asymptotic limit after chemotherapy is always greater than one cell, a cure will never be effected (Clare et al., 2000). However, if it is less than one cell, a cure could reasonably be expected (Clare et al., 2000).

Thus, it could be concluded from the above demonstrated mathematical models that the metastatic growth rate is proportional to the size of the tumor from which it was derived (Clare et al., 2000).Secondly, the probability of metastasis is related to the primary tumor doubling time (Clare et al., 2000).

Effects of surgery on Metastasis: According to Retsky et al., the distribution included a sharp peak of relapse at 18 months and another broad peak at 60 months after surgery (Clare et al., 2000). They attributed the bimodal distribution to the effects of surgery on promoting metastatic growth (Clare et al., 2000). The higher rates of relapse among patients with triple-negative breast cancer appeared attributable to residual disease at the time of surgery, highlighting a need for either more effective neoadjuvant therapies or defined adjuvant, residual disease protocols (Anders \& Carey, 2009). Metastasis is unpredictable in onset and it exponentially increases the clinical impact to the host (Talmadge \& Fidler., 2010).

Evidence 1: The cell line MDA-MB-231 was derived from the pleural effusion of a breast cancer patient suffering from widespread metastasis years after removal of her primary tumor (Andy et al., 2005). Individual MDA-MB-231 cells grown and tested as single-cell-derived progenies (SCPs) had distinct metastatic abilities and tissue tropisms despite having similar expression levels of genes constituting a validated Rosetta-type poor prognosis signature (Andy et al., 2005). These different 
metastatic behaviors, including different tropisms to bone and lungs, were associated with discrete variation in overall gene expression patterns (Andy et al., 2005).

Recurrence: TNBC has a characteristic pattern of recurrence. During the 6 years of observation, the metastatic disease occurred in one-third of all TNBC patients (including these 9 patients initially with stage IV disease): $15 \%$ in the brain, $14 \%$ in the lungs, $11 \%$ in the bones, $8 \%$ in the liver, and $14 \%$ patients had locoregional relapse (Rakha et al., 2008). The most common site of the first recurrence was lungs (Rakha et al., 2008). The highest risk of recurrence was during the first 3 years after primary treatment, and then, during the next 2 years of observation, it did not change significantly (Rakha et al., 2008). Dent et al. reported that in their study the risk of recurrence rose sharply from the date of diagnosis, peaked at 1-3 year interval and then dropped quickly (Anders \& Carey, 2009). Liedtke et al reported that patients with triple-negative breast cancer have higher rates of recurrence in visceral organs and soft tissue, with lower rates of bone disease, compared with hormone-sensitive counterparts (Anders \& Carey, 2009). Similar results were reported among 344 lymph node-negative primary breast tumors subject to molecular classification (Anders \& Carey, 2009). Lung relapse was most abundantly seen among patients with breast tumors classified as basal-like breast tumors (Anders \& Carey, 2009).

Factors influencing recurrence were tumor size and systemic adjuvant chemotherapy, while factors influencing overall survival were tumor size, nodal status, adjuvant/neoadjuvant treatment, and metastases (Pogoda et al., 2013). The tumor size was responsible for recurrence despite lack of involvement of lymph nodes (Pogoda et al., 2013).

Table 4: Cumulative hazard of metastases

\begin{tabular}{|c|c|c|c|c|}
\hline $\begin{array}{c}\text { Site of } \\
\text { metastases }\end{array}$ & $\begin{array}{c}\text { After } \\
\text { 1 year (\%) }\end{array}$ & $\begin{array}{c}\text { After } \\
\text { 2 years (\%) }\end{array}$ & $\begin{array}{c}\text { After } \\
\text { 3 years (\%) }\end{array}$ & $\begin{array}{c}\text { After } \\
\text { 5 years (\%) }\end{array}$ \\
\hline Brain & 4.3 & 12 & 16 & 17.6 \\
\hline Lungs & 3.8 & 10.7 & 15.1 & 15.7 \\
\hline Liver & 4.2 & 6.5 & 9.1 & 9.1 \\
\hline Bones & 4.3 & 6.7 & 8.1 & 9.4 \\
\hline $\begin{array}{c}\text { Local } \\
\text { recurrence }\end{array}$ & 3.9 & 13.3 & 13.9 & 14.6 \\
\hline
\end{tabular}

Source: Triple-Negative Breast Cancer and PTEN (Phosphate and Tensin Homologue) loss are predictors of BRCA1 Germline Mutations in women with Earlyonset and familial Breast Cancer, but not in women with isolated late-onset breast cancer, (2012) (Phuah et al., 2012). 
South American Journal of Clinical Research

Special Edition 2016

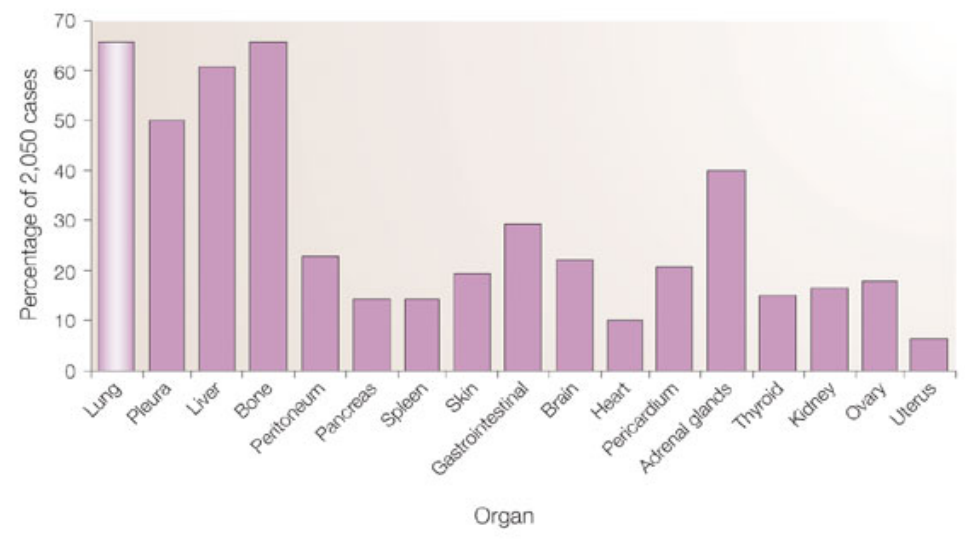

Copyright (c) 2005 Nature Publishing Group Nature Reviews | Cancer

Figure 2: Most common metastasis sites of breast cancer at autopsy

Source: Breast cancer metastasis: markers and models, (2005) (Weigel et al., 2005).

Below is the illustration of Breast cancer metastasis prognostic markers:

\begin{tabular}{|c|c|c|c|}
\hline Marker & Use in clinic & $\begin{array}{c}\text { Metastatic } \\
\text { determinants }\end{array}$ & Details \\
\hline Tumor Size & Established & $\begin{array}{l}\text { Tumors under } 2 \mathrm{~cm} \\
\text { in diameter have a } \\
\text { low risk of } \\
\text { metastasis; } \\
\text { Tumors of } 2-5 \mathrm{~cm} \\
\text { have a high risk of } \\
\text { metastasis; } \\
\text { Tumors over } 5 \mathrm{~cm} \\
\text { have a very high } \\
\text { risk of metastasis }\end{array}$ & $\begin{array}{l}\text { Independent } \\
\text { Prognosis marker }\end{array}$ \\
\hline $\begin{array}{l}\text { Axillary lymph-node } \\
\text { status }\end{array}$ & Established & $\begin{array}{l}\text { If there are no } \\
\text { lymph-node } \\
\text { metastases, the risk } \\
\text { of metastasis is } \\
\text { low, if lymph-node } \\
\text { metastases are } \\
\text { present, the risk of } \\
\text { metastasis is high; } \\
\text { the presence of } \\
\text { over } 4 \text { lymph-node } \\
\text { metastases is } \\
\text { associated with } \\
\text { very high } \\
\text { metastasis risk }\end{array}$ & $\begin{array}{l}\text { Related to tumor } \\
\text { size }\end{array}$ \\
\hline Histological grade & Established & $\begin{array}{l}\text { Grade } 1 \text { tumors } \\
\text { have a low risk of } \\
\text { metastasis, } \\
\text { Grade } 2 \text { tumors } \\
\text { have } \\
\text { intermediate risk of } \\
\text { metastasis, }\end{array}$ & $\begin{array}{l}\text { Related to tumor } \\
\text { size }\end{array}$ \\
\hline
\end{tabular}


Special Edition 2016

\begin{tabular}{|c|c|c|c|}
\hline & & $\begin{array}{l}\text { Grade } 3 \text { tumors } \\
\text { have a high risk of } \\
\text { metastasis. }\end{array}$ & \\
\hline Angioinvasion & $\begin{array}{l}\text { Established in } \\
\text { patients with } \\
\text { lymph-node- } \\
\text { negative tumors }\end{array}$ & $\begin{array}{lr}\text { The presence } & \text { of } \\
\text { tumor emboli in } \\
\text { over } 3 \text { blood } \\
\text { vessels } \\
\text { associated } \\
\text { metastasis }\end{array}$ & $\begin{array}{l}\text { In patients with } \\
\text { lymph-node- } \\
\text { negative tumors }\end{array}$ \\
\hline $\begin{array}{l}\text { uPA/PAI1 protein } \\
\text { level }\end{array}$ & $\begin{array}{l}\text { Newly established } \\
\text { marker }\end{array}$ & $\begin{array}{l}\text { High protein levels } \\
\text { of uPA and PAI1 } \\
\text { are associated with } \\
\text { high metastasis risk }\end{array}$ & $\begin{array}{l}\text { Independent } \\
\text { Prognosis marker }\end{array}$ \\
\hline $\begin{array}{ll}\text { Steroid- } & \text { receptor } \\
\text { expression } & \end{array}$ & $\begin{array}{l}\text { Established for } \\
\text { adjuvant therapy } \\
\text { decision }\end{array}$ & $\begin{array}{l}\text { Low steroid- } \\
\text { receptor levels are } \\
\text { associated } \\
\text { metastasis }\end{array}$ & $\begin{array}{l}\text { Short term } \\
\text { predictor of } \\
\text { metastasis risk ( } 5 \\
\text { years); related to } \\
\text { histological grade }\end{array}$ \\
\hline $\begin{array}{l}\text { Gene-Expression } \\
\text { Profiling }\end{array}$ & $\begin{array}{l}\text { Currently being } \\
\text { tested }\end{array}$ & $\begin{array}{l}\text { A 'good signature' } \\
\text { of } 70 \text { genes is } \\
\text { associated with low } \\
\text { metastasis risk; } \\
\text { A 'poor signature' } \\
\text { of } 70 \text { genes is } \\
\text { associated with } \\
\text { high metastasis } \\
\text { risk. }\end{array}$ & $\begin{array}{l}\text { Tested in patients } \\
\text { with lymph-node- } \\
\text { negative tumors }\end{array}$ \\
\hline
\end{tabular}

Source: Breast cancer metastasis: markers and models, (2005) (Weigel et al., 2005).

Role of Chemokines in the process of Metastasis to lungs: Breast cancer tissue highly expresses the chemokine receptor, chemokine (L-X-C motif) receptor 4 (CXCR4) while its ligand, chemokine (C-X-C motif) ligand 12 (CXCL 12) is predominantly expressed in lymph nodes, lung, liver and bone marrow (Scully et al., 2012). Organs with higher expression of CXCL 12 are associated with being common sites of metastatic breast cancer (Scully et al., 2012). Muller et al. demonstrated that the CXCR4-CXC12 interaction and the cadherin family encouraged breast cancer metastasis (Scully et al., 2012). Down-regulation of E-cadherin and up-regulation of $\mathrm{N}$-cadherin was shown to be a determinant in the outgrowth of metastatic breast cancer cells (Scully et al., 2012).

Evidence 1: There is compelling evidence that the stromal cells aid migration of tumor cells (Scully et al., 2012). The majorities of stromal cells within breast cancer are fibroblasts and are usually referred to as carcinoma associated fibroblasts (CAFs) (Scully et al., 2012). Immunodeficient nude mice when injected with both human CAFs \& MCF7-ras human breast cancer cell lines, exhibited enhanced breast tumor growth and angiogenesis when compared to mice injected with normal human fibroblasts (Scully et al., 2012).

In a similar manner, tumor-stroma interactions, occurring via soluble growth factors, cytokines and chemokines, remodeling of the extracellular matrix, or direct cell-cell adhesion, are critical for tumor growth, migration, and metastasis (Fantozzi $\&$ Christofori, 2006). Alteration of the expression or function of adhesion molecules responsible for the adhesion of breast cancer cells to themselves, to stromal cells, or to tumor matrix, including integrin family members, immunoglobulin-domain cell adhesion molecules (such as L1 and NCAM), cadherin family members, or other cell surface receptors (such as CD44), contributes predominantly to late stage tumor 
progression and metastatic dissemination of cancer cells (Fantozzi \& Christofori, 2006). The cross-talk and interactions between tumor cells and the surrounding stroma, the extracellular matrix (ECM), and infiltrating cells of the immune system are constantly modulating tumor development (Fantozzi \& Christofori, 2006). The formation of new blood vessels (angiogenesis) is crucial for the growth and persistence of primary solid tumors and their metastases, and it has been assumed that angiogenesis is also required for metastatic dissemination, because an increase in vascular density will allow easier access of tumor cells to the circulation (Fantozzi \& Christofori, 2006). Induction of angiogenesis precedes the formation of malignant tumors, and increased vascularization seems to correlate with the invasive properties of tumors and thus with the malignant tumor phenotype (Fantozzi \& Christofori, 2006). Pulmonary involvement is common for TNBC metastasis patients' because of the circulation of entire cardiac output through the lung capillary network (Gluz et al., 2009). Most commonly, lung metastatic lesions initiate at the level of small pulmonary arterioles, where they must either burst through or otherwise breach both the tight endothelial junctions of lung blood vessels and the underlying basement membrane (Gupta \& Massagué, 2006). Once in the lung parenchyma, metastatic cells might survive and grow in this unique microenvironment, which contains highly organized extracellular matrix and specialized cell types for the purpose of respiration (Gupta \& Massagué, 2006).

Through the research, a molecular switch has been discovered according to which the TNBC cells mature as amoeba-like protrusions which then escape from a primary tumor to metastasize throughout the body (Weill Cornell Medical College, 2013, January 14). Thus, the role of miRNA was examined in the spread of TNBC, which accounts for $15 \%$ to $25 \%$ of all the breast tumors (Weill Cornell Medical College, 2013, January 14). Secondly, the process of focal adhesion signaling cascade was found to be important modulator for organ-specific relapse (Smid et al., 2008).

Evidence 2: In breast cancer, the TGF $\beta$ and NF- $\kappa B$ pathways had been implicated in lung metastasis (Gupta \& Massagué, 2006). During in vivo lung metastasis of breast-cancer cells a gene-expression signature was identified that was highly enriched in mediators of pulmonary metastasis (Gupta \& Massagué, 2006). This diverse set of genes encoded for secreted factors (including epiregulin, CXCL1, and SPARC), cell-surface receptors (e.g., VCAM1 and IL13Ra2), extracellular proteases (e.g., MMP1 and MMP2), and intracellular effectors (e.g., Id1 and COX2), which cooperated to promote lung metastasis (Gupta \& Massagué, 2006). Significantly, these genes were further validated in a cohort of primary breast tumors, where expression of these genes correlated with lung metastatic relapse in the corresponding patients (Gupta \& Massagué, 2006).

Evidence 3: For the lung relapse patients, Focal adhesions cascade played an important role (Smid et al., 2008). Focal adhesions are specific types of large protein complexes through which the cytoskeleton of a cell connects to and communicates with the extracellular matrix (Smid et al., 2008). Of the focal adhesion genes that were annotated by KEGG, many are up-regulated in the luminal A subtype and downregulated in tumors from patients who had a lung relapse (Smid et al., 2008). Because very few patients in the luminal A subtype had relapses to the lung, it seemed that the involved focal adhesion molecules impede a lung relapse (Smid et al., 2008).

Evidence 4: In both laboratory cells and in animal studies, Vivek Mittal, $\mathrm{PhD}$, of well Cornell Medical College along with his colleagues identified the function of miR-708 which is located on cell membrane of endoplasmic reticulum, in order to suppress the protein neuronatin (Weill Cornell Medical College, 2013, January 14). According to this research, neuronatin controls the level of calcium in and out of the organelle (Weill Cornell Medical College, 2013, January 14). It is calcium that provided legs to the cancer cells escape a primary tumor (Weill Cornell Medical 
College, 2013, January 14). So, miR-708 acted as a suppressor of metastasis by keeping neuronatin in check (Weill Cornell Medical College, 2013, January 14). If miR-708 is itself suppressed, there was an increase in production of neuronatin proteins, which then allowed more calcium to leave the endoplasmic reticulum and activated a cascade of genes that turn on migratory pathways leading to metastasis (Weill Cornell Medical College, 2013, January 14). Moreover, it was found that delivering synthetic miR-708, carried by bubbles of fat, blocked metastatic outgrowth of TNBC in the lungs of mice (Weill Cornell Medical College, 2013, January 14).

Evidence 5: The intravenous injection of radiolabeled B16 melanoma cells revealed that by 24 hours after injection into the circulation, $0.1 \%$ or less of the cells were still viable, and less than $0.01 \%$ of tumor cells within the circulation survived to produce experimental lung metastases (Talmadge \& Fidler, 2010).

Evidence 6: Wnt signaling:

Wnt family members were the first proto-oncogenes to be discovered by an MMTV-mediated insertion-activation mechanism (Fantozzi \& Christofori, 2006). Transgenic expression of Wnt-1 in the mammary gland of transgenic mice resulted in mammary adenocarcinomas with metastasis to lymph nodes and lungs (Fantozzi \& Christofori, 2006).

Evidence 7: To identify genes that mediated lung metastasis testing was done on parental MDA-MB-231 cells and the 1834 sub-line (an in vivo isolate with no enhancement in bone metastatic behavior) by injection into the tail vein of immunodeficient mice (Andy et al., 2005). Metastatic activity was assayed by bioluminescence imaging (BLI) of luciferase-transduced cells as well as gross examination of the lungs at necropsy (Andy et al., 2005). The 1834 cells exhibited limited but significant lung metastatic activity compared with the parental population (Andy et al., 2005). When 1834-derived lung lesions were expanded in culture and reinoculated into mice, these cells (denoted LM1 subpopulations) showed increased lung metastatic activity (Andy et al., 2005).

To test this, a cohort of 82 breast cancer patients was used in a univariate Cox proportional hazards model to relate the expression level of each lung metastasis signature gene with clinical outcome (Andy et al., 2005). Twelve of the 54 genes are significantly associated with lung-metastasis-free survival, including MMP1, CXCL1 and PTGS2 (Andy et al., 2005). A cross-validated multivariate analysis using a linear combination of each of the 54 genes weighted by the univariate results distinguished between patients with a high risk and those with a low risk for developing lung metastasis (10-year lung-metastasis-free survival of $56 \%$ versus $89 \%, \mathrm{P}=0.0018$ ) (Andy et al., 2005). When a similar multivariate analysis was performed by weighting each gene by a t-statistic derived from a comparison of its expression between the LM2 cell lines with that of the parental MDA-MD-231 cells, the 54 genes again distinguished patients at high risk for developing lung metastasis (62\% versus $88 \%, \mathrm{P}$ $=0.01$ ) (Andy et al., 2005). These results indicate that a clinically relevant subgroup of patients might express certain combinations of lung metastasis signature genes (Andy et al., 2005). To identify patterns of gene expression associated with aggressive lung metastatic behavior, a transcriptomic microarray analysis of the highly and weakly lung-metastatic cell populations was performed (Andy et al., 2005). The gene list obtained from a class comparison between parental and LM2 populations was filtered to exclude genes that were expressed at low levels in a majority of samples and to ensure a threefold or higher change in expression level between the two groups (Andy et al., 2005). A total of 95 unique genes (113 probe sets) met these criteria: 48 were overexpressed and 47 under expressed in cell populations most metastatic to the lungs (Andy et al., 2005).

Evidence 8: A subset of biologically interesting genes overexpressed in the 54 gene list was selected for functional validation (Andy et al., 2005). These genes 
included those encoding the epidermal-growth-factor family member epiregulin (EREG), which is a broad-specificity ligand for the HER/ErbB family of receptors, the chemokine GRO1/CXCL1, the matrix metalloproteinases MMP1 (collagenase 1) and MMP2 (gelatinase A), the cell adhesion molecule SPARC, the interleukin-13 decoy receptor IL13R $\alpha 2$ and the cell adhesion receptor VCAM1 (Andy et al., 2005). These genes encoded secretory or receptor proteins, indicating possible roles in the tumor cell microenvironment (Andy et al., 2005). In addition to these genes, we included the transcriptional inhibitor of cell differentiation and senescence ID1 (Andy et al., 2005). To determine whether these genes have a causal function in lung metastasis, they were overexpressed by retroviral infection in the parental population either individually, in groups of three, or in groups of six (Andy et al., 2005). Only cells overexpressing ID1 alone were modestly more active at forming lung metastases than cells infected with vector controls. Combinations of these genes invariably led to more aggressive metastatic activity (Andy et al., 2005).

\section{Detection of Breast Cancer Metastasis}

1. Biopsies of affected organs (Scully et al., 2012).

2. Radiological evaluations (Scully et al., 2012).

3. Imaging methods and serum tumor markers (Scully et al., 2012).

4. Bone Scintigraphy (Scully et al., 2012).

5. Liver echography (Scully et al., 2012).

6. Chest X-ray (Scully et al., 2012).

Evidence 1: Nicolini et al. emphasized that the inclusion of serum tumor markers is an important factor in the post-operative monitoring of breast cancer patients (Scully et al., 2012).

Evidence 2: Another suggestion is to have intense post-operative follow up which include consultations every 4-6 months, physical examination and evaluation of serum carcinoembryonic antigen (CEA), tissue polypeptide antigen (TPA) and breast cancer associated Ag 115, D8/DF3 (CA15.3), at each visit (Scully et al., 2012).

Evidence 3: Circulating Tumor cells are the tumor cells originating from primary sites or metastases that circulate in patients' blood stream (Scully et al., 2012). Circulating tumor cells are recognized as playing important roles in the metastasis of carcinomas and their analysis enables the prediction of metastatic relapse and progression (Scully et al., 2012).

\section{Management of TNBC metastasis through novel “Targeted" therapeutic agents}

Clinical and pathological risk factors, such as age, tumor size and steroid receptor status, are commonly used to assess the likelihood of metastasis development (Chuang et al., 2007). A better understanding of patterns of metastatic spread might influence adjuvant therapy and surveillance decisions and determine which investigations and therapies are appropriate once distant disease has been diagnosed (Kennecke et al., 2010).

Factors influencing Chemotherapy Choice: There are many agents including single agent or a combination regimen available for treating TNBC, yet there is no sequence of treatment that could be ideally applied to all the patients suffering (Schott et al., 2015). However, below given is the illustration of the principles that can guide the choice of therapy in the first- or later-line setting (Schott et al., 2015).

1. Tumor burden - Tumor burden (the extent of disease detected on imaging or clinical exam and/or the presence of tumor-related symptoms) can impact on whether single-agent chemotherapy or a combination regimen is to be administered (Schott et al., 2015). 
2. The patient with a limited tumor burden or minimal cancer-related symptoms, preference is given to the sequential use of single-agent chemotherapy, which is less toxic ultimately resulting in better overall survival (Schott et al., 2015).

3. Patients with a large tumor burden in symptomatic disease due to location of specific metastatic lesions e.g., dyspnea due to diffuse lung metastasis), preference is given to the use of a combination regimen to obtain a higher response rate (Schott et al., 2015).

I. Combination Regimen containing anthracycline drugs: doxorubicin (Adriamycin) and epirubicin (Pharmorubicin) (Scully et al., 2012).

II. Combination Regimen containing taxane: paclitaxel (Taxol) and docetaxel (Taxotere) (Scully et al., 2012).

III. Single agent Chemotherapy drug, i.e., platinum based drugs widely used for treating triple negative and basal-like tumors: cisplatin (Platinol AQ and carboplatin (Paraplatin, Paraplatin AQ) (Scully et al., 2012).

IV. Single agent Chemotherapy drug, i.e., Eribulin: eribulin mesylate (Halaven) improved overall survival (OS) of patients with triple-negative and HER2-negative metastatic breast cancer (Inman, 2014).

Table 6. Therapeutic strategies, confirmed and in development, for triple-negative breast cancer

\begin{tabular}{|c|c|}
\hline $\begin{array}{c}\text { Therapeutic } \\
\text { Strategy or Target }\end{array}$ & Status of Development \\
\hline $\begin{array}{c}\text { Anthracycline-/taxane-based } \\
\text { chemotherapy }\end{array}$ & $\begin{array}{c}\text { Proven efficacy, phase II/III } \\
\text { clinical trials }\end{array}$ \\
\hline Platinum agents & $\begin{array}{c}\text { Active agents, phase II } \\
\text { clinical trials }\end{array}$ \\
\hline EGFR inhibition & $\begin{array}{c}\text { Modest activity, phase II } \\
\text { clinical trials }\end{array}$ \\
\hline Antiangiogenesis & $\begin{array}{c}\text { Efficacy in subset analysis, } \\
\text { phase III trials }\end{array}$ \\
\hline PARP1 inhibition & $\begin{array}{c}\text { Safety illustrated, efficacy results } \\
\text { anticipated, phase I/II trials }\end{array}$ \\
\hline Src inhibition & Modest activity, phase II trials \\
\hline HDAC inhibition & $\begin{array}{c}\text { Activity in preclinical studies, } \\
\text { early clinical development }\end{array}$ \\
\hline MEK inhibition & Activity in preclinical studies \\
\hline
\end{tabular}

Source: Biology, Metastatic Patterns and treatment of patients with Triple-Negative Breast Cancer, (2009) (Anders et al., 2009).

Survival outcomes for patients with metastatic triple-negative breast cancer: According to NCCN guidelines, treatment of Triple negative breast cancer is based both on tumor size and cellular characteristics (Ismail-Khan \& Bui, 2010). Oncologists tend to treat patients with triple negative breast cancer with more aggressive chemotherapy, both in the neoadjuvant and the adjuvant setting (IsmailKhan \& Bui, 2010). Progression-free survival is estimated to be four months at best in TNBC for first line therapy, even with Avastin-based therapy (Ismail-Khan \& Bui, 2010).

Evidence 1: Miller et al demonstrated a significant improvement in progressionfree survival $(11.8$ vs 5.9 months, $\mathrm{HR}=0.60, \mathrm{P}<.001)$ when adding bevacizumab to paclitaxel chemotherapy compared with single-agent paclitaxel alone in first-line 
treatment of metastatic disease (Ismail-Khan \& Bui, 2010). Examining the TNBC subset of patients in this study confirmed the same improvement $(\mathrm{HR}=0.53,95 \%$ confidence interval $=0.40-0.70$ ) (Ismail-Khan \& Bui, 2010). Thus, it could be concluded that Avastin combination for first line therapy could be considered while treating patients with metastatic triple negative breast cancer (Ismail-Khan \& Bui, 2010).

Evidence 2: As presented in the plenary session of the American Society of Clinical Oncology (ASCO) meeting in 2009, the results of a randomized phase II study with BSI-201 (a PARP Inhibitor) showed benefit in patients with TNBC who had two or fewer previous lines of chemotherapy (Ismail-Khan \& Bui, 2010). When BSI-201 was combined with gemcitabine and carboplatin, the clinical benefit rate improved to 62 percent when compared to the gemcitabine and carboplatin alone arm at 21 percent $(\mathrm{p}<0002)$ [21]. (Clinical benefit rate is defined as complete response plus partial response plus stable disease lasting six months or more) (Ismail-Khan \& Bui, 2010). In addition, the overall response rate was notably improved in the BSI$201 \mathrm{arm}$ at 48 percent compared to the control arm at 16 percent (Ismail-Khan \& Bui, 2010). Progression-free survival was improved to 6.9 months in the BSI-201 arm of the study versus 3.3 months in the gemcitabine and carboplatin alone arm (IsmailKhan \& Bui, 2010).

Evidence 3: Mammography showed that primary breast tumors have an average doubling time of 157 days, varying from 44 to more than 1800 days during exponential growth (Talmadge \& Fidler, 2010). Thus, the growth of a tumor from initiation to a size of $1 \mathrm{~cm}$ required an average of 12 years (Talmadge \& Fidler, 2010). This finding is significant because a $1-\mathrm{cm}$ tumor has $10^{9}$ cells and has undergone at least 30 doublings from tumor initiation to diagnosis (Talmadge \& Fidler, 2010). On the basis of these parameters and the observations that a tumor burden of approximately $1,000 \mathrm{~cm}^{3}$ was considered lethal, the time from diagnosis to mortality represents 10 doubling times from a $1-\mathrm{cm}$ tumor and shorter time frame (Talmadge \& Fidler, 2010). Therefore, three quarters of a tumor's life history had occurred prior to diagnosis, and metastasis could occur prior to diagnosis (Talmadge \& Fidler, 2010).

Table 7: Survival after recurrence depending on the site of metastases

\begin{tabular}{|c|c|c|c|}
\hline $\begin{array}{l}\text { Site of } \\
\text { metastases }\end{array}$ & $\begin{array}{l}\text { No. of } \\
\text { patients }\end{array}$ & $\begin{array}{l}\text { Median } \\
\text { (months) }\end{array}$ & $\begin{array}{l}\text { 95 \% CI } \\
\text { (months) }\end{array}$ \\
\hline Brain & 34 & 6.3 & $4.9-7.7$ \\
\hline Lungs & 33 & 9.8 & $1.7-17.8$ \\
\hline Local recurrence & 31 & 9 & $7.5-10.6$ \\
\hline Bones & 26 & 5.5 & $2.7-8.4$ \\
\hline Liver & 19 & 3.5 & $0-7.7$ \\
\hline
\end{tabular}

Source: Biology, Metastatic Patterns and treatment of patients with Triple-Negative Breast Cancer, (2009) (Anders \& Carey, 2009).

\section{Discussion}

Once a diagnosis of a primary cancer is established, the urgent question is whether it is localized or metastasized (Talmadge \& Fidler, 2010). Prognostic and predictive factors are well established in early-stage breast cancer, but less is known about which metastatic sites would be affected. As described above, triple-negative breast cancer is highly responsive to primary anthracycline and anthracycline/taxane chemotherapy; 
however, a high risk of relapse remains if the tumor is not eradicated. Both preclinical and clinical studies indicated that tumors with BRCA1 dysfunction, the majority of which are triple negative, harbor deficient double-stranded DNA break repair mechanisms and are sensitive to DNA-damaging chemotherapeutic agents, such as platinum agents (i.e., cisplatin and carboplatin). The association between BRCA1 dysfunction and triple-negative breast cancer has led to several neoadjuvant/adjuvant and metastatic studies evaluating platinum agents in the setting of triple-negative breast cancer (Anders \& Carey, 2009). The ability to determine the initiation time of metastatic growth would enable to determine the likelihood of a patient having metastatic recurrence (Clare et al., 2000). As predicted, the initiation time relies significantly on the model of the cancer's natural history (Clare et al., 2000).

3 main growth stages of metastasis:

a. Dormant single metastatic cell (Clare et al., 2000).

b. Avascular stage modeled by Gompertzian growth, with a limiting size of approx. $10^{5}$ cells (Clare et al., 2000).

The size is limited by the fact that the cells must be nourished by diffusion of nutrients from the existing vasculature (Clare et al., 2000).

c. Vascular stage also modeled by Gompertzian growth with a limiting size of approx. $10^{12}$ cells (Clare et al., 2000).

The transition between these three phases is considered as stochastic (Clare et al., 2000).

Although the specific adjuvant regimens that might be most effective for TNBC are still being determined, third-generation chemotherapy regimens using dose dense or metronomic polychemotherapy are among the most effective tools presently available (Ismail-Khan \& Bui, 2010). The role of specific chemotherapy agents in the treatment of TNBC remains incompletely defined and warrants careful review to ensure that the most effective therapy is delivered while minimizing unnecessary toxicity (IsmailKhan \& Bui, 2010). Platinum agents have seen renewed interest in TNBC based on a growing body of preclinical and clinical data suggesting encouraging activity (IsmailKhan \& Bui, 2010). Taxanes and anthracyclines are active in TNBC and remain important agents but have not shown specific benefit over non-TNBC (Ismail-Khan \& Bui, 2010). There was a rapid rise in risk of recurrence following diagnosis (Dent et al., 2007).

Moreover, it is been observed that there is a peak rise of recurrence at 1-3 years of interval (Dent et al., 2007). Distal recurrence rarely preceded by local recurrence (Dent et al., 2007). Local recurrence was not found to be predictive of distal recurrence (Dent et al., 2007). Also, there was an increased mortality rate in the first 5 years (Dent et al., 2007). Majority of deaths occurred in first 5 years due to Rapid progression to distant recurrence (Dent et al., 2007).

\section{Conclusion}

Metastasis is frequently a final and fatal step in the progression of solid malignancies. Metastatic spread of cancer cells is the main cause of death of breast cancer patients, and elucidation of the molecular mechanisms underlying this process is a major focus in cancer research. As in many other metastatic cancer types, specific molecular changes occurring within both the tumor cells and the tumor microenvironment contribute to the detachment of tumor cells from the primary tumor mass, invasion into the tumor stroma, intravasation into nearby blood vessels or lymphatics, survival in the bloodstream, extravasation into and colonization of the target organ and, finally, metastatic outgrowth.

Advanced modeling approaches, technological ingenuity, and an emphasis on clinical validation have all contributed to a rapid rate of recent progress. It could be envisioned metastasis as one possible outcome from the somatic evolution of 
cancerous cells that have lost control over the integrity of their genome. As these tumors go on to spew cells and soluble factors into the circulation, the entire body becomes an evolutionary playing field. Until the primary tumor is diagnosed and surgically removed, one might even imagine a period of dynamic interplay between cells in the primary mass and those that have already undergone dissemination.

One of the reported aspects is that the aggressiveness of a tumor, i.e., the ability to metastasize, is driven by a distinct set of genes, different from those involved in the capacity to home, survive, and proliferate in a particular organ. This might tie in with the self-seeding theory and the seed and soil theory of Paget. The latter theory proposes that specific organs are in some way predisposed targets for secondary growth. This may reflect the necessity for the primary tumor to express a certain genetic module to invade specific organs. The self-seeding theory offers the view that dislodged cancer cells may either reenter the primary tumor bed or otherwise colonize a distant organ, the latter cell possibly needing additional (genetic) properties. Metastatic cells are genetically unstable with diverse karyotypes, growth rates, cellsurface properties, antigenicities, immunogenicities, marker enzymes, and sensitivity to various therapeutic agents resulting in biological heterogeneity (Talmadge \& Fidler, 2010). Review of the history of pioneering observations and discussions of current controversies should increase understanding of the complex and multifactorial interactions between the host and selected tumor cells that contribute to fatal metastasis and should lead to the design of successful therapy. Yet the process of tumor metastasis remains controversial. The present study reveals how aggressive primary tumorigenic function could be mechanistically coupled to greater lung metastatic potential. The ongoing challenge is to identify new prognostic markers that are more directly related to disease and that can more accurately predict the risk of metastasis in individual patients (Chuang et al., 2007).

Research is underway to find out:

a. Which chemotherapy drugs work best for triple negative tumors or basal-like tumors (Scully et al., 2012).

b. Whether there are different treatments needed for triple negative tumors and basal-like tumors (Scully et al., 2012).

c. Whether chemotherapy given with less time between treatments (dose dense) is more effective (Scully et al., 2012).

\section{Limitations}

1. To identify low risk and high-risk groups.

2. To pinpoint those patients who are most likely to benefit from systemic adjuvant treatment retrospectively.

3. To identify the potential marker to be tested in large patient cohorts with a long follow-up period.

4. Financial burden to test all new tumor markers.

\section{References}

[1]. Amorotti, G.F., Chiodoni, C., \& Shen, F. (2014). Suppression of Invasion and Metastasis of Triple-Negative Breast Cancer Lines by Pharmacological or Genetic Inhibition of Slug Activity. Neoplasia, 16(12), 1047-1058. doi: 10.1016/j.neo.2014.10.006.

[2]. Anders, C.K., \& Carey, L.A. (2009). Biology, Metastatic Patterns and treatment of patients with TripleNegative Breast Cancer. Clin Breast Cancer, 9(2): S73-S81. doi: 10.3816/CBC.2009.s.008. (PMCID: PMC2919761).

[3]. Anderson, A., Choy, C., \& Neman, J., et al. (2013). Metastatic breast cancer to the brain: A clinical primer for Translational Investigation. In: Madame Curie Bioscience Database [Internet]. Austin (TX): Landes Bioscience; Retrieved from: http://www.ncbi.nlm.nih.gov/books/NBK154381/. 


\section{South American Journal of Clinical Research Special Edition 2016}

[4]. Andy J. Minn, A.J., Gupta, G.P., \& Siegel, P.M. et al. (2005). Genes that mediate breast cancer metastasis to lung. Nature, 436, 518-524. doi: 10.1038/nature03799.

[5]. Boyle, P. (2012). Triple-negative breast cancer: epidemiological considerations and recommendations. Annals of Oncology, 23 (6): vi7-vi12. doi:10.1093/annonc/mds187.

[6]. Breast cancer. org. Metastatic or Distant Recurrence Symptoms. Retrieved from: http://www.breastcancer.org/symptoms/types/recur_metast/where_recur/metastic

[7]. Chuang, H.Y., Lee, E., \& Liu, Y.T. (2007). Network-based classification of breast cancer metastasis. Molecular Systems Biology, 3: 140. doi: 10.1038/msb4100180.

[8]. Clare, S.E., Nakhlis, F., Carl, \& Panetta, J.C. (2000). Molecular biology of breast metastasis: The use of mathematical models to determine relapse and to predict response to chemotherapy in breast cancer. Breast Cancer Res, 2(6): 430-435. doi: 10.1186/bcr90.

[9]. Deng, C.X. (2006). BRCA1: cell cycle checkpoint, genetic instability, DNA damage response and cancer evolution. Nucleic Acids Research, 34 (5): 1416-1426.doi: 10.1093/nar/gk1010.

[10]. Dent, R., Hanna, W.M., Trudeau, M. (2009).Pattern of metastatic spread in triple negative breast cancer. Breast Cancer Research and Treatment, 115(2), 423-428.

[11]. Dent, R., Trudeau, M., \& Pritchard, K.I., et al. (2007). Triple-negative breast cancer: clinical features and patterns of recurrence. Clin Cancer Res, 13, 4429. doi: 10.1158/1078-0432.CCR-06-3045.

[12]. Dolle, J.M., et al. (2009). Risk factors for triple negative breast cancer in women under the age of 45 years. Cancer Epidemiology Biomarkers \& Prevention. American Association for Cancer Research, 18(4), 1157-66. (PMID: 19336554).

[13]. Fantozzi, A., \& Christofori, G. (2006). Mouse models of breast cancer metastasis. Breast Cancer Research, 8, 212. doi: 10.1186/bcr1530.

[14]. Ford, D., Easton, D.F., \& Stratton, M., et al. (1998). Genetic heterogeneity and Penetrance Analysis of the BRCA1 and BRCA2 genes in Breast Cancer families. The American Society of Human Genetics, 62(3), 676-689. doi: $10.1086 / 301749$.

[15]. Gluz, O., et al. (2009). Triple negative breast cancer--current status and future directions. (2009). Annals of Oncology, 20(12), 1913-27. (PMID: 19901010).

[16]. Gupta, G.P., \& Massagué, J. (2006). Cancer Metastasis: Building a Framework. Cell, 127(4), 679-695. doi:10.1016/j.cell.2006.11.001.

[17]. Gupta, G.P., Nguyen, D.X., \& Chiang, A.C. (2007). Mediators of vascular remodeling co-opted for sequential steps in lung metastasis. Nature, 446, 765-770. doi: 10.1038/nature05760.

[18]. Hedenfalk, I., Duggan, D., \& Chen, Y., et al. (2001). Gene-expression profiles in hereditary breast cancer. $N$ Engl J Med, 344, 539-548. doi: 10.1056/NEJM200102223440801.

[19]. Inman, S. (2014). Eribulin Improves Survival in Metastatic Triple-Negative Breast Cancer. Retrieved from: http://www.onclive.com/web-exclusives/Eribulin-Improves-Survival-in-HER2-Negative-Metastatic-BreastCancer.

[20]. Isakoff, S.J. (2010).Triple-negative breast cancer: role of specific chemotherapy agents. Cancer Journal, 16(1), 53-61 (PMID: 20164691).

[21]. Ismail-Khan, R., \& Bui, M.M. (2010). A review of triple-negative breast cancer. Cancer Control, 17(3), 173176.

[22]. Karsten, U., \& Goletz, S. (2013). What makes cancer stem cell markers different?. Springer Plus, 2, 301. doi: 10.1186/2193-1801-2-301.

[23]. Kassam, F., Enright, K., \& Dent, R., et al. (2009). Survival outcomes for patients with metastatic triplenegative breast cancer: implications for clinical practice and trial design. Clin Breast Cancer, 9(1), 29-33. doi: 10.3816/CBC.2009.n.005.

[24]. Kennecke, H., Yerushalmi, R., \& Woods, R., et al. (2010). Metastatic Behavior of Breast Cancer Subtypes. American Society of Clinical Oncology, 28(20), 3271-3277. doi: 10.1200/JCO.2009.25.9820.

[25]. Korsching, E., Jeffrey, S.S., \& Meinerz, W., et al. Basal carcinoma of the breast revisited: an old entity with new interpretations. Journal of Clinical Pathology, 61(5), 553-60. (PMID: 18326009).

[26]. Maksimenko, J., Irmejs, A., \& Millasevica, M.N., et al. (2014). Prognostic role of BRCA1 mutation in patients with triple-negative breast cancer. Oncol Lett, 7(1), 278-284. doi: 10.3892/ol.2013.1684.

[27]. Marcus, J.N., Watson, P., \& Page, D.L., et al. (1996). Hereditary breast cancer: Pathobiology, Prognosis and BRCA1 \& BRCA2 Gene linkage. Cancer, 15; 77(4), 697-709. 


\section{South American Journal of Clinical Research Special Edition 2016}

[28]. National Cancer Institute. A story of discovery: HER2's Genetic link to Breast Cancer Spurs Development of New treatments. Retrieved from: http://www.cancer.gov/research/progress/discovery/HER2\#.

[29]. Nguyen, D.X., \& Massagué, J. (2007). Genetic determinants of cancer metastasis. Nature Reviews Genetics, 8, 341-352. doi: 10.1038/nrg2101.

[30]. Peshkin, B.N., Alabek, M.L., \& Isaacs, C. (2010). BRCA1/2 Mutations and Triple Negative Breast Cancers. Breast Dis, 32. doi: 10.3233/BD-2010-0306. (PMCID: PMC3870050).

[31]. Pestalozzi, B.C. (2009). Brain metastasis and subtypes of breast cancer. Annals of Oncology, 20 (5), 803-805. doi: 10.1093/annonc/mdp246.

[32]. Phuah, S.Y., Looi, L.M., \& Hassan, N., et al. (2012).Triple-Negative Breast Cancer and PTEN (Phosphate and Tensin Homologue) loss are predictors of BRCA1 Germline Mutations in women with Early-onset and familial Breast Cancer, but not in women with isolated late-onset breast cancer. Breast Cancer Research, 14, R142. doi: $10.1186 /$ bcr3347.

[33]. Pogoda, K., Niwińska, A., \& Murawska, M., et al. (2013). Analysis of pattern, time and risk factors influencing recurrence in triple-negative breast cancer patients. Medical Oncology, 30, 388. doi: 10.1007/s12032012-0388-4.

[34]. Rakha, E.A., Reis-Filho, J.S., \& Ellis, I.O. (2008). Basal-like breast cancer: a critical review. Journal of Clinical Oncology, 26(15), 2568-81 (PMID: 18487574).

[35]. Rhee, J., Han, S.W., \& Oh, D.Y., et al. (2008). The clinicopathologic characteristics and prognostic significance of triple negativity in node-negative breast cancer. BMC Cancer, 8, 307. doi: 10.1186/1471-2407-8307 (PMID: 18947390).

[36]. Schott, F.A., Hayes, D.F., \& Vora, S.R. (2015). Systemic treatment of metastatic breast cancer in women: Chemotherapy. Retrieved from: http:/www.uptodate.com/contents/systemic-treatment-of-metastatic-breastcancer-in-women-chemotherapy

[37]. Scully, O.J., Bay, B.H., \& Yip, G., et al. (2012). Breast cancer metastasis. Cancer Genomics and Proteomics, 9(5), 311-320.

[38]. Seal, M.D., \& Chia, S.K. (2010). What is the difference between triple negative and basal breast cancers? Cancer Journal: The Journal of Principles \& Practice of Oncology, 16(1), 12-6. (PMID: 20164685).

[39]. Sirohi, B., Arnedos, M., \& Popat. S., et al. (2008).Platinum-based chemotherapy in triple-negative breast cancer. Annals of Oncology, 19(11), 1847-52. (PMID: 18567607).

[40]. Smid, M., Wang, Y., \& Zhang, Yi., et al. (2008). Subtypes of Breast Cancer Show Preferential Site of Relapse. Cancer Research, 68, 3108; doi: 10.1158/0008-5472.

[41]. Talmadge, J.E., \& Fidler, I.J. (2010). AACR Centennial Series: The Biology of Cancer Metastasis: Historical Perspective. Cancer Res, 70, 5649. doi: 10.1158/0008-5472.CAN-10-1040.

[42]. Tseng, L.M., Hsu, N.C., \& Chen, S.C., et al. (2013). Distant metastasis in triple-negative breast cancer. Neoplasma, 60(3), 290-4. doi: 10.4149/neo_2013_038. (PMID: 23373998).

[43]. Weigel, B., Peterse, J.L., \& Veer, L.J.V. (2005). Breast cancer metastasis: markers and models. Nature Reviews Cancer, 5, 591-602. doi: 10.1038/nrc1670.

[44]. Weill Cornell Medical College. (2013, January 14). Aggressive breast cancer's metastatic path revealed. ScienceDaily. Retrieved October 29, 2015 from www.sciencedaily.com/releases/2013/01/130114124930.htm [45]. Zhang, X.H.F., Giuliano, M., \& Trivedi, M.V., et al. (2013). Metastasis Dormancy in Estrogen ReceptorsPositive Breast Cancer. Clinical Cancer Research, 19, 6389. doi: 10.1158/1078-043.

[46]. Zhou, W., et al. (2010). Long-term survival of women with basal-like ductal carcinoma in situ of the breast: a population-based cohort study. BMC Cancer, 10, 653 (PMID: 21118480). 